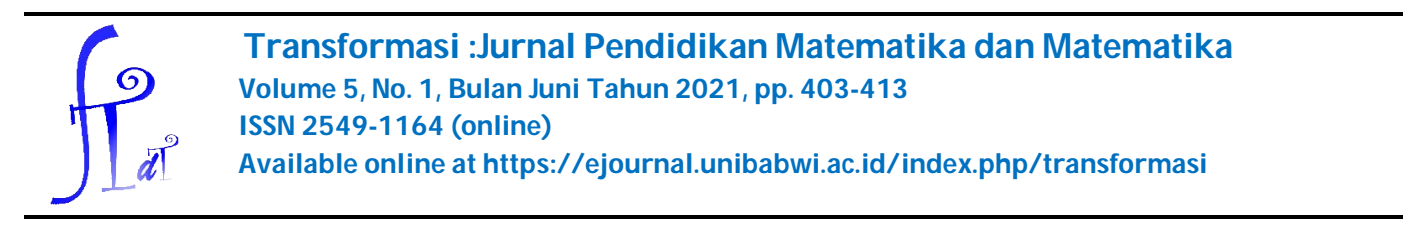

\title{
MATHEMATICS ANXIETY DAN HASIL BELAJAR : ADAKAH PENGARUHNYA?
}

\author{
Agis Yusup Safari ${ }^{1}$, Adi Ihsan Imami2 \\ 1,2Program Studi Pendidikan Matematika, Universitas Singaperbangsa Karawang \\ email korespondensi : agisyusupsafari@gmail.com
}

Diterima : (27-01-2021), Revisi: (18-02-2021), Diterbitkan : (31-03-2021)

\begin{abstract}
ABSTRAK
Kurangnya hasil belajar matematika siswa kelas IX di salah satu SMP di Rawamerta menjadi latar belakang penelitian ini. Sehingga penelitian ini ditujukan untuk menelaah adanya pengaruh mathematics anxiety terhadap hasil belajar siswa di Sekolah tersebut. Seluruh siswa kelas IX di Sekolah tersebut menjadi populasi dalam penelitian, dengan sampelnya sebanyak 72 siswa yang tersebar di enam kelas dan diperoleh dengan teknik simple random sampling. Data mathematics anxiety dan hasil belajar matematika diperoleh dari angket dan dokumentasi yang kemudian dianalisis menggunakan analisis deskriptif dan analisis inferensial dengan regresi linear sederhana. Kesimpulan dari penelitian ini adalah mathematics anxiety berpengaruh negatif terhadap hasil belajar matematika dengan persamaan regresi $y=124,790-1,112 x$ dan koefisien determinasi sebesar 0,748 . Artinya $74,8 \%$ hasil belajar matemtika siswa dipengaruhi oleh mathematics anxiety.
\end{abstract}

Kata Kunci : ex post facto, kecemasan matematika, hasil belajar matematika

\section{ABSTRACT}

The lack of mathematics learning outcomes of grade IX students at a junior high school in Rawamerta is the background of this research. So this research was conducted to determine the effect of mathematics anxiety on student learning outcomes at the school. All students in grade IX in the school became the population in the study, with a sample of 72 students spread over six classes and obtained by simple random sampling technique. Data on mathematics anxiety and mathematics learning outcomes are collected from questionnaires and documentation which are then analyzed using descriptive analysis and inferential analysis with simple linear regression. The conclusion of this study is mathematics anxiety has a negative effect on mathematics learning outcomes with the regression equation $y=124,790-1,112 x$ and a coefficient of determination of 0.748 . This means that $74.8 \%$ of students' mathematics learning outcomes are influenced by mathematics anxiety.

Keywords : ex post facto, mathematics anxiety, mathematics learning outcomes 


\section{Pendahuluan}

Matematika adalah subjek ilmu pengetahuan yang kegunaannya dibutuhkan dalam banyak kegiatan dikehidupan sehari-hari. Matematika amat penting dalam kehidupan, siapapun harus menguasainya (Apiati et al., 2019; Ikrimah et al., 2017; Rochmawati \& Hariastuti, 2017). Tanpa matematika, ilmu pengetahuan lain seperti fisika, kimia, biologi, bahkan ilmu sosial akan sulit diterapkan dalam kehidupan. Tak heran, jika disetiap jenjang pendidikan selalu ada mata pelajaran matematika (Arigiyati, 2017; Kusuma et al., 2018; Nugraha et al., 2020). Melihat pentingnya peran matematika, banyak pihak yang mengharapkan berhasilnya pembelajaran matematika. Salah satu indikator keberhasilan pembelajaran matematika dapat dilihat dari hasil belajar siswa.

Hasil belajar mengacu pada perubahan kemampuan siswa untuk memperoleh pengetahuan dan keterampilan setelah melakukan kegiatan pembelajaran (Nuraisyah \& Izzati, 2020). Namun kenyataannya, belum semua hasil belajar matematika siswa sesuai dengan harapan. Berdasarkan pemaparan yang disampaikan pendidik matematika kelas IX di salah satu SMP Negeri di Rawamerta menunjukan bahwa 80,5\% siswa kelas IX dalam ulangan harian matematika masih dibawah standar ketuntasan. Adapun standar ketuntasan matematika kelas IX yaitu 75, artinya hanya 19,5\% yang sudah mencapai standar ketuntasan. Dengan demikian, hasil belajar matematika kelas IX di sekolah tersebut masih tergolong sangat rendah.

Hasil belajar matematika siswa yang rendah tersebut dapat disebabkan oleh berbagai faktor, diantaranya adalah faktor kognitif dan faktor afektif. Faktor kognitif yang menyebabkan rendahnya hasil belajar matematika antara lain ketidaktahuan siswa terhadap materi yang diajarkan, dan pengetahuan dasar matematika yang lemah. Salah satu penyebab rendahnya hasil belajar matematika siswa adalah kemampuan kognitif (Zakiah \& Khairi, 2019).

Selain itu matematika biasanya menjadi momok menakutkan, sulit, menegangkan, dan membosankan bagi sebagian besar siswa. Bahkan beberapa siswa meninggalkan kelas ketika pelajaran matematika berlangsung. Hal tersebut mengindikasikan bahwa kurangnya sikap positif siswa terhadap matematika. Kasmedia (Istiqomah \& Prihatnani, 2019) menyatakan bahwa kurangnya sikap positif siswa terhadap matematika dapat menyebabkan respon dan interaksi antara pendidik 
dengan siswa menjadi berkurang, kemampuan dan keseriusan siswa dalam belajar matematika juga akan berkurang, serta sikap siswa yang kurang memahami tentang tujuan dan isi mata pelajaran matematika.

Ranah sikap atau yang sering disebut ranah afektif merupakan aspek yang banyak melibatkan kemampuan yang berhubungan dengan bagaimana sikap siswa dalam menghadapi pembelajaran. Faktor penting yang dapat mempengaruhi hasil belajar meliputi faktor psikologis, seperti sikap, kepribadian, minat, bakat, motivasi dan kecerdasan (Suratman et al., 2019). Salah satu aspek afektif yaitu kecemasan. Menurut Kamus Besar Bahasa Indonesia (KBBI), kecemasan atau cemas diartikan sebagai gelisah atau tidak tentram hati (karena khawatir, takut). Kecemasan yang dihadapi siswa dalam matematika sering disebut dengan mathematics anxiety (kecemasan matematika).

Mathematics anxiety atau kecemasan matematika berbeda dengan kecemasan pribadi. Orang yang mengalami gangguan, ketakutan, ketegangan, dan ketidaknyamanan dalam masalah dan situasi yang melibatkan matematika dikatakan mengalami mathematics anxiety. Mathematics anxiety didefinisikan sebagai rasa khawatir ketika seseorang menghadapi matematika, seperti ketika mereka harus menyelesaikan masalah matematika, memanipulasi angka, atau ketika mereka dihadapkan pada situasi evaluasi terkait matematika (Luttenberger et al., 2018). Mathematics anxiety juga dapat diartikan sebagai tekanan saat belajar matematika atau dalam kelas matematika (Lai et al., 2015).

Mathematics anxiety dapat dilihat ketika siswa menghadapi beberapa aspek yaitu mata pelajaran matematika, proses pembelajaran matematika, pendidik mata pelajaran matematika, dan tes atau evaluasi matematika (Setyaningsih, 2016). Mathematics anxiety menjadikan siswa tidak fokus dan sulit menerima serta memahami apa yang pendidik sampaikan terkait konsep matematika. Hal ini, tentu saja dapat berakibat negatif terhadap hasil belajar matematika siswa. Zakariya (Kusmaryono \& Ulia, 2020) juga mengungkapkan bahwa dampak negatif dari tingginya tingkat kecemasan siswa yaitu tidak optimalnya kinerja akademik siswa pada pembelajaran.

Berdasarkan uraian diatas, peneliti ingin mengetahui apakah mathematics anxiety mempengaruhi hasil belajar siswa kelas IX di salah satu SMP Negeri di Rawamerta. 


\section{MetodePenelitian}

Dalam penelitian ini mathematics anxiety (X) menjadi variabel bebas, sedangkan variabel terikatnya adalah hasil belajar matematika (Y). Karena variabel bebas (mathematics anxiety) dalam penelitian ini sudah dimiliki siswa atau sudah terjadi sebelumnya dan tidak dapat dimanipulasi, maka penelitian ini menggunakan penelitian ex post facto. Kerlinger (Lestariningsih \& Sholichah, 2017) mengatakan penelitian ex pose facto adalah penelitian empiris yang sistematis, dengan pengontrolan variabel bebas tidak secara langsung karena sudah ada atau tidak bisa dimanipulasi.

Sebanyak 241 siswa yang tersebar dalam 6 kelas yaitu kelas IXA sampai kelas IXF salah satu SMP Negeri di Rawamerta menjadi populasi dalam penelitian ini. Keadaan populasi ditunjukkan pada Tabel 1 berikut.

Tabel 1. Populasi Penelitian

\begin{tabular}{ccccccc}
\hline Kelas IX & A & B & C & D & E & F \\
\hline Jumlah Siswa & 40 & 40 & 40 & 41 & 40 & 40 \\
\hline Total & \multicolumn{7}{c}{241} \\
\hline
\end{tabular}

Berdasarkan populasi yang ada, 72 siswa yang tersebar di 6 kelas menjadi sampel dalam penelitian ini, yang diambil menggunakan sampling acak sederhana (simple random sampling). Teknik sampling acak sederhana adalah teknik pengambilan sampel dari anggota populasi yang dilakukan secara acak tanpa memperhatikan tingkat keseluruhan (Sutiyono et al., 2020). Adapun penentuan sampel menggunakan rumus Solvin (Sidqi \& Rachmawati, 2019).

Kuesioner dan dokumentasi digunakan untuk pengumpulan data penelitian. Metode kuesioner dilaksanakan dengan memberikan angket tentang mathematics anxiety kepada siswa yang menjadi sampel penelitian. Angket kecemasan disusun berdasarkan aspek kecemasan yang diungkapkan oleh Setyaningsih (2016) dengan sedikit modifikasi sesuai kebutuhan. Angket memuat 25 pernyataan, dengan 13 pernyataan positif dan 12 pernyataan negatif.

Angket memiliki empat pilihan jawabanya itu Sangat Setuju (SS), Setuju (S), Tidak Setuju (TS), dan Sangat Tidak Setuju (STS). Pilihan ragu-ragu dihilangkan untuk menghindari jawaban yang bersifat ganda. Tiap pertanyaan yang bersifat positif diberi skor $4,3,2$, dan 1 . Sedangkan untuk tiap pertanyaan yang bersifat negatif diberi skor 1, 2, 3, dan 4 . Angket diberikan 3 hari sebelum pelaksanaan UAS semester ganjil tahun pelajaran 2020/ 2021. 
Proses menghimpun nilai UAS matematika semester ganjil tahun pelajaran 2020/ 2021 sebagai data hasil belajar matematika dilakukan dengan metode dokumentasi. Soal UAS sebagai instrumen penelitian dibuat oleh dinas pendidikan Kabupaten Karawang.

Sebelum dilakukan analisis, data mathematics anxiety dan hasil belajar matematika siswa dikategorikan berdasarkan pedoman (Sudijono, 2011). Analisis deskriptif dan analisis inferensial digunakan sebagai teknik analisis data dalam penelitian ini. Analisis deskriptif digunakan untuk mendeskripsikan variabel penelitian mathematics anxiety dan hasil belajar matematika siswa yang diperoleh dalam bentuk skor rata-rata $(\bar{X})$, standar deviasi (SD), nilai minimum (Min), dan nilai maksimum (Max). Hasil analisis inferensial dimaksudkan untuk menjawab hipotesis penelitian yang telah dirumuskan (Yusri, 2018). Analisis inferensi yang digunakan adalah analisis regresi linier sederhana. Analisis regresi linier sederhana merupakan metode yang digunakan untuk mengetahui pengaruh variabel independent terhadap variabel dependent (Juliyanti \& Pujiastuti, 2020).

\section{Hasil dan Pembahasan}

Gambaran karakteristik sampel penelitian dapat diketahui dari hasil analisis deskriptif berdasarkan variabel mathematics anxiety dan hasil belajar siswa melalui skor rata-rata $(\bar{X})$, standar deviasi, nilai minimum, dan nilai maksimum pada tabel 2 berikut.

Tabel 2. Statistik Deskriptif

\begin{tabular}{ccccc}
\hline Keterangan & $\overline{\boldsymbol{X}}$ & SD & Min & Max \\
\hline $\mathrm{X}$ & 64,91 & 8,72 & 45,42 & 86,76 \\
\hline $\mathrm{Y}$ & 52,61 & 11,21 & 30 & 79
\end{tabular}

Tabel 3 berikut ini menunjukkan penjelasan hasil pengelompokan data kecemasan matematis siswa sesuai kategori yang digunakan.

Tabel 3. Hasil Skor Mathematics Anxiety Siswa

\begin{tabular}{cccc}
\hline Kriteria Skor & Kategori & Frekuensi & $\mathbf{( \% )}$ \\
\hline Nilai $\leq \mathbf{5 1 , 8 3}$ & Sangat Rendah & 7 & 9,72 \\
\hline $\mathbf{5 1 , 8 3}<$ Nilai $\leq 60,55$ & Rendah & 13 & 18,06 \\
\hline $\mathbf{6 0}, \mathbf{5 5}<$ Nilai $\leq 69,27$ & Sedang & 34 & 47,22 \\
\hline $\mathbf{6 9 , 2 7}<$ Nilai $\leq 77,99$ & Tinggi & 13 & 18,06 \\
\hline Nilai $>77,99$ & Sangat Tinggi & 5 & 6,94 \\
\hline
\end{tabular}


Tabel 3 menunjukkan Mathematics Anxiety Siswa pada kategori sedang memiliki frekuensi terbanyak dengan jumlah 34 atau 47,22\%. Sedangkan frekuensi paling rendah diperoleh pada kategori sangat tinggi dengan 5 dari 72 siswa atau 6,94\%. Nilai rata-rata dari keseluruhan respon mathematics anxiety berada pada kategori sedang dengan skor 64,91. Hal tersebut sejalan dengan pendapat (Handayani, 2019; Juliyanti \& Pujiastuti, 2020; Ulya \& Rahayu, 2017) yang menyatakan bahwa sebagian besar siswa mempunyai kecemasan pada kategori sedang.

Tabel 4 berikut menunjukkan hasil analisis deskripsi mengenai aspek kecemasan siswa.

Tabel 4. Aspek Mathematics Anxiety

\begin{tabular}{ccc}
\hline No. & Aspek Mathematics Anxiety & $\mathbf{\%}$ \\
\hline 1 & Mata Pelajaran Matematika & 24,71 \\
\hline 2 & Pembelajaran Matematika & 23,65 \\
\hline 3 & Pendidik Matematika & 22,52 \\
\hline 4 & Evaluasi (Tes/ Ujian) & 29,12 \\
\hline
\end{tabular}

Berdasarkan Tabel 4 diketahui bahwa mathematics anxiety lebih didominasi pada aspek mata pelajaran matematika dan evaluasi (tes/ujian) dibandingkan aspek lainnya dengan persentase sebesar 24,71\% dan 29,12\%.

Tabel 5. Kategori Hasil Belajar Siswa

\begin{tabular}{cccc}
\hline Kriteria Skor & Kategori & Frekuensi & $\mathbf{( \% )}$ \\
\hline Nilai $>69,42$ & Sangat Tinggi & 7 & 9,72 \\
\hline $\mathbf{5 8 , 2 1}<$ Nilai $\leq 69,42$ & Tinggi & 9 & 12,50 \\
\hline $\mathbf{4 7 , 0 1}<$ Nilai $\leq 58,21$ & Sedang & 27 & 37,50 \\
\hline $\mathbf{3 5 , 8 0}<$ Nilai $\leq 47,01$ & Rendah & 27 & 37,50 \\
\hline Nilai $\leq \mathbf{3 5 , 8 0}$ & Sangat Rendah & 2 & 2,78 \\
\hline
\end{tabular}

Tabel 5 menunjukkan bahwa hasil belajar matematika siswa kelas IX SMP Negeri 1 Rawamerta didominasi pada kategori rendah dan sedang dengan jumlah 27 siswa masing-masing atau 37,50\% pada tiap kategori. Kategori sangat rendah memiliki frekuensi terkecil yang dicapai oleh 2 siswa atau 2,78\%. Rata-rata dari keseluruhan nilai hasil belajar matematika berada pada kategori sedang, dengan skor 52,61 .

Selanjutnya, Kolomogorov-Smirnov (dengan taraf signifikansi 0,05) digunakan untuk menguji normalitas hasil angket mathematics anxiety dan hasil belajar matematika. Tujuan dari uji normalitas residual adalah untuk mengetahui apakah variabel residual atau pengganggu dalam model regresi berdistribusi normal (Setiani, 
2018).

Tabel 6. Hasil Uji Normalitas

$\begin{array}{lccc} & \text { Statistic } & \text { Df } & \text { Sig. } \\ \text { Unstandardized Residual } & 0,088 & 72 & 0,201\end{array}$

Tabel 6 menunjukkan nilai signifikansi dari uji normalitas sebesar 0,201 > 0,05. Artinya data berdistribusi normal, sehingga dapat dilanjutkan ke uji linearitas untuk kelinearan hubungan antara mathematics anxiety dan hasil belajar matematika siswa.

Tabel 7. Hasil Uji Linearitas

\begin{tabular}{lccccc}
\hline & Sum of Squares & df & Mean Square & F & Sig. \\
\hline (Combined) & 8732,611 & 60 & 145,544 & 8,677 &, 000 \\
\hline Linearity & 6671,909 & 1 & 6671,909 & 397,783 &, 000 \\
\hline Deviation from Linearity & 2060,702 & 59 & 34,927 & 2,082 &, 092 \\
\hline
\end{tabular}

Tabel 7 menunjukkan nilai Sig. Deviation from Linearity sebesar 0,092 >0,05, yang dapat diartikan bahwa data tidak terjadi penyimpangan terhadap linieritas. Sehingga data dapat digunakan untuk tahapan selanjutnya, yaitu menentukan persamaan regresinya.

Tabel 8. Persamaan Regresi

\begin{tabular}{lcccccc}
\hline \multirow{2}{*}{ Model } & \multicolumn{2}{c}{ Unstandarized Coefficients } & $\begin{array}{c}\text { Standarized } \\
\text { Coefficients }\end{array}$ & t & Sig. \\
\cline { 3 - 5 } & B & Std. Error & Beta & & \\
\hline \multirow{2}{*}{1} & (Constant) & 124,790 & 5,049 & & 24,717 & 0,000 \\
& X & $-1,112$ & 0,077 & $-0,865$ & $-14,423$ & 0,000 \\
\hline
\end{tabular}

Dari Tabel 8 dapat diperoleh persamaan regresi linier sederhana yaitu $y=124,790-1,112 x$. Selain persamaan regresi linier sederhana, Tabel 8 juga dapat digunakan untuk menguji hipotesis. Pengujian hipotesis digunakan untuk menunjukkan pengaruh mathematics anxiety terhadap hasil belajar matematika. Adapun hipotesis yang diuji adalah:

$H_{0}$ : Tidak terdapat pengaruh yang signifikan antara mathematics anxiety terhadap hasil belajar matematika.

$H_{1}$ : Terdapat pengaruh yang signifikan antara mathematics anxiety terhadap hasil belajar matematika.

Kriteria pengujian hipotesis:

Jika nilai Sig.> 0,05 maka $H_{0}$ diterima.

Jika nilai Sig. $\leq 0,05$ maka $H_{0}$ ditolak. 
Tabel 8 juga menunjukkan bahwa nilai signifikan variabel mathematics anxiety (X) adalah $0,000<0,05$. Artinya $H_{0}$ ditolak dan $H_{1}$ diterima. Sehingga dapat dikatakan bahwa terdapat pengaruh yang signifikan antara mathematics anxiety terhadap hasil belajar matematika. Setiap kenaikan satu satuan mathematics anxiety maka memberikan dampak penurunan pada hasil belajar matematika sebesar -1,112. Artinya terdapat pengaruh negatif antara mathematics anxiety terhadap hasil belajar matematika. Semakin tinggi mathematics anxiety siswa menyebabkan semakin rendahnya hasil belajar matematika, dan sebaliknya. Sesuai dengan pendapat Rahman (Aryani \& Hasyim, 2018), bahwa terdapat pengaruh negatif antara mathematics anxiety dengan hasil belajar matematika.

Untuk mengetahui besarnya pengaruh mathematics anxiety terhadap hasil belajar matematika digunakan koefisien determinasi.

Tabel 9. Koefisien Determinasi

\begin{tabular}{ccccc}
\hline Model & R & R Square & $\begin{array}{c}\text { Adjusted R } \\
\text { Square }\end{array}$ & $\begin{array}{c}\text { Std. Error of the Esti- } \\
\text { mate }\end{array}$ \\
\hline 1 & 0,865 & 0,748 & 0,745 & 5,66342 \\
\hline
\end{tabular}

Tabel 9 menunjukkan bahwa koefisien determinasi bernilai 0,748 artinya hubungan mathematics anxiety terhadap hasil belajar matematika adalah 74,8\%, dan $25,3 \%$ sisanya ditentukan variabel lain yang tidak dianalisis dalam penelitian ini.

Hasil penelitian menunjukan bahwa mathematics anxiety mempengaruhi hasil belajar matematika siswa dengan kuat. Hal ini sejalan dengan pandangan Slameto (Mukholil, 2018), yaitu faktor internal meliputi kecemasan, motivasi, sikap terhadap pendidikan, kebiasaan belajar, kesehatan, kesiapan mental dan fisik, umur dan jenis kelamin dapat mempengaruhi hasil belajar. Untuk mendapatkan hasil belajar yang maksimal, pendidik dapat mengantisipasi mathematics anxiety yang terjadi.

Pendidik berperan penting dalam membantu mengatasi mathematics anxiety siswa. Salah satu cara yang dapat dilakukan pendidik yaitu dengan meningkatkan kepercayaan diri siswa terhadap pembelajaran matematika, pendidik dapat membekali siswa dengan soal-soal latihan dari tahap sederhana, sedang, hingga sulit agar dapat memecahkan soal-soal tersebut. Sebagai pemegang peranan penting dalam pendidikan, diharapkan para pendidik menciptakan kondisi pembelajaran matematika yang menarik dan menyenangkan. Selain itu pendidik juga dituntut untuk dapat membuat inovasi-inovasi terbaru dalam pembelajarannya agar pembelajaran tidak monoton dan membosankan. Sehingga pembelajaran yang dilaku- 
kan dapat menarik perhatian peserta didik dan mengurangi kecemasannya. Akibatnya sikap negatif dan mathematics anxiety dapat berkurang dan akan meningkatnya hasil belajar matematika.

\section{Kesimpulan}

Hasil penelitian menunjukkan adanya pengaruh yang signifikan antara mathematics anxiety terhadap hasil belajar matematika. Sehingga disarankan pendidik dapat menciptakan pembelajaran yang menarik dan menyenangkan yang dapat mengurangi mathematics anxiety siswa. Hasil penelitian ini diharapkan dapat memberikan pengembangan metode pembelajaran yang dapat mengurangi mathematics anxiety. Penelitian lanjutan dapat dilakukan tentang faktor penyebab rendahnya hasil belajar siswa selain karena mathematics anxiety.

\section{Daftar Pustaka}

Apiati, V., Heryani, Y., \& Muslim, S. R. (2019). Etnomatematik dalam Bercocok Tanam Padi dan Kerajinan Anyaman Masyarakat Kampung Naga. Mosharafa: Jurnal Pendidikan Matematika, 8(1), 107-118. https:/ / doi.org/ 10.31980/ mosharafa.v8i1.417

Arigiyati, T. A. (2017). Pengaruh Minat dan Perhatian Orang Tua Terhadap Prestasi

Belajar Matematika Siswa SMP. Transformasi: Jurnal Pendidikan Matematika Dan Matematika, 1(1), 27-35.

Aryani, T. D., \& Hasyim, M. (2018). Pengaruh Kecemasan Matematis, Problem Stress

Matematika Dan Self-Regulated Learning Terhadap Hasil Belajar Matematika

Siswa. Aksioma: Jurnal Program Studi Pendidikan Matematika, 7(2), 243-252.

Handayani, S. D. (2019). Pengaruh Kecemasan Matematika terhadap Pemahaman

Konsep Matematika. SAP (Susunan Artikel Pendidikan), 4(1), 59-65.

Ikrimah, I., Rahmi, M., \& Darmawan, R. N. (2017). Studi Etnomatematika di Kalangan

Petani Desa Kelir Kecamatan Kalipuro. Transformasi: Jurnal Pendidikan Matematika Dan Matematika, 1(1), 50-59.

Istiqomah, U., \& Prihatnani, E. (2019). Peningkatan Hasil Belajar dan Sikap Siswa terhadap Matematika melalui Joyful Learning. Mosharafa: Jurnal Pendidikan Matematika, $8(3)$ 471-482. https:/ / journal.institutpendidikan.ac.id/ index.php/ mosharafa/ article/ view/ m v8n3_11

Juliyanti, A., \& Pujiastuti, H. (2020). Pengaruh Kecemasan Matematis dan Konsep

Diri Terhadap Hasil Belajar Matematika Siswa. Prima: Jurnal Pendidikan 
Matematika, 4(2), 75-83.

Kusmaryono, I., \& Ulia, N. (2020). Interaksi Gaya Mengajar dan Konten Matematika sebagai Faktor Penentu Kecemasan Matematika. Mosharafa: Jurnal Pendidikan Matematika, 9(1), 143-154.

Kusuma, A. P., Safa'udin, M., \& Rahayu, R. (2018). Eksperimentasi Model Pembelajaran TPS dan TAI terhadap Hasil Belajar Matematika pada Materi Lingkaran. Jurnal Tecnoscienza, 3(1), 29-40.

Lai, Y., Zhu, X., Chen, Y., \& Li, Y. (2015). Effects of mathematics anxiety and mathematical metacognition on word problem solving in children with and without mathematical learning difficulties. PloS One, 10(6), e0130570.

Lestariningsih, L., \& Sholichah, B. (2017). Pengaruh Sikap Siswa Pada Matematika Terhadap Hasil Belajar Materi Persamaan Kuadrat. Jurnal Pendidikan Matematika RAFA, 3(2) , 207-213. https:/ / doi.org/ 10.19109/jpmrafa.v3i2.1742

Luttenberger, S., Wimmer, S., \& Paechter, M. (2018). Spotlight on math anxiety.

Psychology Research and Behavior Management, 11, 311-322. https:/ / doi.org/ 10.2147/ PRBM.S141421

Nugraha, S. A., Sudiatmi, T., \& Suswandari, M. (2020). Studi pengaruh daring learning terhadap hasil belajar matematika kelas iv. Jurnal Inovasi Penelitian, 1(3), 265-276.

Nuraisyah, M., \& Izzati, N. (2020). Self - Efficacy pada Hasil Belajar Peserta Didik Materi Bentuk Aljabar Madrasah Tsanawiyah Tanjungpinang. Jurnal Pendidikan $\begin{array}{lll}\text { Matematika } & \text { RAFA, 6(2), 100-108. }\end{array}$ https:/ / doi.org/ https:/ / doi.org/ 10.19109/jpmrafa.v6i2.5453

Rochmawati, A., \& Hariastuti, R. M. (2017). Analisis Pemahaman Siswa pada Pokok Bahasan Garis dan Sudut Berdasarkan Gaya Kognitif Field Independent dan Field dependent. Transformasi: Jurnal Pendidikan Matematika Dan Matematika, $1(1), 1-15$.

Setiani, Y. (2018). Pengaruh Tingkat Kecerdasan Visual-Spasial terhadap Literasi Kuantitatif Mahasiswa Calon Guru Matematika. Kreano, Jurnal Matematika Kreatif-Inovatif, $9(1)$ 38-46. https:// doi.org/ https:/ / doi.org/ 10.15294/ kreano.v9i1.12258

Setyaningsih, T. D. (2016). Keefektifan Problem Based Learning dengan Seting Kolaboratif Ditinjau dari Prestasi Belajar Aljabar, Kemampuan Berpikir Kritis, dan Kecemasan Siswa SMP. http:/ / eprints.uny.ac.id/ id/ eprint/ 43313

Sidqi, M. B., \& Rachmawati, L. (2019). Pengaruh Nilai Matematika Terhadap Hasil Belajar Ekonomi Siswa Kelas X IIS SMA Negeri 17 Surabaya. Jurnal Pendidikan Ekonomi (JUPE), 7(3), 81-91.

Sudijono, A. (2011). Evaluasi Pendidikan. In Jakarta: Raja Grafindo Persada.

Suratman, A., Afyaman, D., \& Rakhmasari, R. (2019). Pembelajaran berbasis TIK 
terhadap hasil belajar matematika dan motivasi belajar matematika siswa. Jurnal Analisa, 5(1), 41-50.

Sutiyono, S., Nurimani, N., \& Suyanto, A. (2020). Perbedaan Hasil Belajar Matematika melalui Metode Diskusi dan Demonstrasi pada Materi Bangun Ruang Sisi Datar. Prosiding Seminar Nasional Pendidikan STKIP Kusuma Negara II, 25-33.

Ulya, H., \& Rahayu, R. (2017). Pembelajaran etnomatematika untuk menurunkan kecemasan matematika. Jurnal Mercumatika: Jurnal Penelitian Matematika Dan Pendidikan Matematika, 2(1), 16-23.

Yusri, A. Y. (2018). Pengaruh Model Pembelajaran Problem Based Learning Terhadap Kemampuan Pemecahan Masalah Matematika Siswa Kelas Vii Di Smp Negeri Pangkajene. Mosharafa: Jurnal Pendidikan Matematika, 7(1), 51-62. https:/ / doi.org/ 10.31980/ mosharafa.v7i1.341

Zakiah, Z., \& Khairi, F. (2019). Pengaruh Kemampuan Kognitif Terhadap Prestasi Belajar Matematika Siswa Kelas V SDN Gugus 01 Kecamatan Selaparang. El Midad, 11(1), 85-100. 